\title{
Rehabilitation as a Positive Obligation
}

\section{Sonja Meijer}

Department of Criminal Law and Criminology, Vrije Universiteit Amsterdam, De Boelelaan 1105, 1081 HV Amsterdam, The Netherlands

s.meijer@vu.nl

\begin{abstract}
Although the emphasis in European penal policy now lies on the rehabilitative aim of imprisonment, the concept of rehabilitation remains vague and is being interpreted differently in different European countries. This paper looks at rehabilitation from a legal perspective and aims to clarify the current meaning and content of the principle of rehabilitation. It does this by focusing on the questions of whether and on what grounds rehabilitation can be considered a positive obligation on the part of the State and, if so, what the consequences are of recognising rehabilitation as a positive obligation.
\end{abstract}

\section{Keywords}

European Court of Human Rights - human dignity - life imprisonment - positive obligations - penal policy - rehabilitation

\section{$1 \quad$ Introduction}

While punishment remains one of the aims of imprisonment, the emphasis in European penal policy now lies on the rehabilitative aim of imprisonment, particularly towards the end of longer prison sentences. ${ }^{1}$ Recently, the European Court of Human Rights (ECHR) has explicitly stated that states have

1 See Dickson v. the United Kingdom, 4 December 2007, para. 75; Vinter and others $v$. The United Kingdom, 9 July 2013, para. 115 and Harakchiev and Tolumov v. Bulgaria, 8 July 2014, paras. 243-246. 
a positive obligation to ensure rehabilitation ${ }^{2}$ and has insisted that the emphasis on rehabilitation has become a mandatory factor that member states need to take into account when developing their penal policies. ${ }^{3}$

The principle of rehabilitation remains vague, however. Interpretations of the principle differ between the disciplines and professional groups involved (law, criminology and social work), but also within these groups. ${ }^{4}$ Furthermore, this principle is explained in various ways in different European countries.

This paper looks at rehabilitation from a legal point of view and aims to clarify the current meaning and content of the principle of rehabilitation. It does this by focusing on the questions of whether and on what grounds rehabilitation can be considered a positive obligation of the part of the state and, if so, what the recognition of rehabilitation as a positive obligation implies. Does rehabilitation entail certain obligations for states and, if so, what kind of obligations?

To answer the first part of this question, I will analyse the recent case law of the ECHR. Subsequently, by making a comparative legal analysis between the relevant German (case) law, in which rehabilitation is recognized as a constitutional right, and Dutch (case) law, in which rehabilitation is considered an important aim of sentencing, but is not considered a 'right' as such, I will answer the second part of the question: what are the consequences of recognizing rehabilitation as a positive obligation? Does recognition as a positive obligation make any difference for the individual prisoners involved?

The concept of rehabilitation has been a source of controversy in the past. Rehabilitation was often seen by critics as being contrary to individual rights. Rehabilitation, it was argued, could be used as a pretext for protracted periods of incarceration, and disproportionate and intrusive treatment methods, such as drug therapies, were used. This misuse of the concept of rehabilitation often helped to produce the opposite effect to that desired. ${ }^{5}$ After the concept

2 Murrayv. The Netherlands (para. 104).

3 Khoroshenko v. Russia, 30 June 2015, para. 121.

4 C. Morgenstern, 'Der Resozialisieringsgrundsatz', Social reintegration as the dominant narrative for community punishment in Germany?' in: G. Robinson and F. McNeill, Community Punishment. European perspectives (Abingdon: Routledge, 2015), pp. 72-94.

5 F. Allen, The decline of the rehabilitative ideal (New Haven, Ст: Yale University Press, 1981); F.T. Cullen and K.E. Gilbert, Reaffirming rehabilitation (Cincinnati, он: Anderson, 1982); 
of rehabilitation was discredited in the 1980 , the term was superseded by the concept of 'social rehabilitation' or 'social (re)integration'. More recently, rehabilitation has regained legitimacy if applied within desert boundaries. ${ }^{6}$

Rehabilitation has also been referred to in a positive light by the ECHR and the срт. ${ }^{7}$ Over time, the principle has gained importance within the Court's case law, on the basis of various provisions of the Convention. The contours of rehabilitation have gradually been defined in the case law of the ECHR. According to the ECHR, the European Convention on Human Rights does not guarantee a right to rehabilitation, as such. However, the Court has explicitly stated that "the emphasis on rehabilitation and reintegration has become a 'mandatory factor' that member states need to take into account

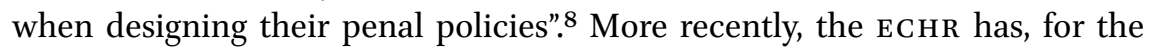
first time, indicated that rehabilitation is a "positive obligation" on the part of the state. ${ }^{9}$

The principle is also inherent in several instruments to which the Court attaches considerable importance, despite their non-binding character (see, for instance, Rule 6 of the European Prison Rules, which provides that all detention shall be managed so as to facilitate the reintegration into free society of persons who have been deprived of their liberty).${ }^{10}$ The principle of rehabilitation is also reflected in international law. For instance, Article 10(3) of the ICCPR requires that "the penitentiary system shall comprise the treatment of persons, the essential aim of which shall be their reformation and social rehabilitation". On a European level, social rehabilitation is mentioned in two European Framework decisions as an aim of (cross-border) enforcement of custodial sentences and probation orders and other types of alternative

E. Rotman, 'Do offenders have a constitutional rights to rehabilitation?', 77 The Journal of Criminal Law \& Criminology (1986) 1023-1068, at 1024.

F.T. Cullen and K.E. Gilbert, op. cit.

7 D. van Zyl Smit and S. Snacken, Principles of European Prison Law (New York, NY: Oxford University Press, 2009), p. 83.

8 See Khoroshenko v. Russia, 30 June 2015, para. 121. It does so, by referring to the cases of Vinter and others $v$. the United Kingdom (paras. 11-116) and Harakchiev and Tolumov v. Bulgaria (paras. 243-246), thereby implying that rehabilitation and resocialization have been a mandatory factor all along.

$9 \quad$ Murrayv. The Netherlands, 26 April 2016, para. 104.

10 See also Rules 33.3, 102.1 and 107.1 of the European Prison Rules, points 6 and 11 of Resolution $76(2)$ of the Committee of Ministers, and paragraphs 2 in fine, 5 and 33 of the Recommendation $2003(23)$ on the management by prison administrations of life sentence and other long-term prisoners. 
sanctions. ${ }^{11}$ However, these rules all remain very general and provide no idea of what rehabilitative policies in prisons should look like in practice.

According to the ECHR, punishment remains one of the aims of imprisonment, but the emphasis in European penal policy has now shifted towards its rehabilitative aim. There is now clear support in European and international law for the principle that all prisoners, including those serving life sentences, should be offered the possibility of rehabilitation and the prospect of release if that rehabilitation is achieved. ${ }^{2}$

Rehabilitation is about respect for human dignity, which represents, as the ECHR has often stated, the very essence of the Convention system. ${ }^{13}$ The ECHR thus follows the German Federal Constitutional Court, which has stated that it would be incompatible with the provision on human dignity in the Basic Law for the state to forcefully deprive an individual of his or her freedom without at least providing that individual with the chance to regain their liberty one day. ${ }^{14}$ It is therefore the duty of prison authorities to strive towards the rehabilitation of all (life) prisoners and that rehabilitation is a constitutional requirement for any society that accepts human dignity as its centrepiece. ${ }^{15}$

Rehabilitation has been recognized as a means of preventing recidivism, but in the last decade and more positively, it has involved the idea of resocialization through the fostering of personal responsibility. The 'progression principle' reinforces the objective of personal responsibility. This principle implies that while serving a sentence, a prisoner should move progressively through the prison system thereby moving from the early days of a sentence, when the emphasis may be on punishment and retribution, to the latter stages, when the emphasis should be on preparation for release. ${ }^{16}$ While one of the

11 See Council Framework Decision 2008/909/JHA of 27 November 2008 on the application of mutual recognition to judgments in criminal matters imposing custodial sentences or measures involving deprivation of liberty for the purpose of their enforcement in the European Union, Articles 3(1), 4(4) and 4(6) and Council Framework Decision 2008/947/JHA of 27 November 2008 on the application of the principle of mutual recognition to judgments and probation decisions with a view to the supervision of probation measures and alternative sanctions, Article 1(1).

12 See Vinter and others $v$. the United Kingdom (paras. 114-115).

13 See Vinter and others $v$. the United Kingdom (para. 113); Pretty v. the United Kingdom, 29 April 2002, para. 65; and V.C. v. Slovakia, 8 November 2011, para. 105. See also para. 4.1.

14 See Vinter and others $v$. the United Kingdom (para. 113); Life Imprisonment Case, 21 June 1977, 45 BVerfGE 187.

15 War Criminal case 72 BVerfGE 105 (1986).

16 See Dickson v. the United Kingdom, 4 December 2007, para. 28 and 75 . 
essential functions of a prison sentence is to protect society, the Court also recognizes the legitimate aim of a policy of progressive social reintegration for those serving prison terms. This would appear reasonable, although rehabilitation is only possible if states adopt prison policies that provide ample opportunities for prisoners to rehabilitate themselves. It is for this reason that the ECHR acknowledges the merit of measures, such as temporary release, that permit the social reintegration of prisoners even if they have been convicted of violent crimes. ${ }^{17}$

But what does a positive obligation to rehabilitation imply for states? General guidelines on what the principle of rehabilitation means are lacking. It should also be borne in mind that decisions made by the ECHR in particular cases are not necessarily generally applicable to all other cases. An analysis of the ECHR's recent case law can provide us some pointers, however.

First of all, a positive right to rehabilitation requires a penal policy that respects the human dignity of prisoners. ${ }^{18}$ Human dignity is an important justification for rehabilitation as we will see later on and it should therefore also lie on the basis of a penal policy of a state. ${ }^{19}$ As the ECHR has stated, it would be incompatible with human dignity to forcefully deprive a person of his or her freedom without seeking to rehabilitate that person. ${ }^{20}$ In this regard, the ECHR notes that "while Article 3 of the Convention cannot be construed as imposing on the authorities an absolute duty to provide prisoners with rehabilitation of reintegration programmes and activities, such as courses or counselling, it does require the authorities to give life prisoners a chance, however remote, to someday regain their freedom. For that chance to be genuine and tangible, the authorities must also give life prisoners a 'proper opportunity' to rehabilitate themselves."21 It does not, according to the Court, imply that states are responsible for achieving the rehabilitation of life prisoners. This is an obligation of means, not of result.

But what exactly does providing prisoners with 'a proper opportunity' for rehabilitation mean? According to the ECHR, the obligation to provide an opportunity for rehabilitation "entails a positive obligation to secure prison regimes to life prisoners which are compatible with the aim of rehabilitation and

\footnotetext{
17 See Mastromatteo v. Italy, 24 October 2002, para. 72; Maiorano and others v. Italy, 15 December 2009, para. 108; Schemkamper v. France, 18 October 2005, para. 31 and Choreftakis and Choreftakiv. Greece, 17 January 2012, para. 45.

18 Rotman (1986), op. cit., at 1027.

19 See para. 4.1.

$20 \quad$ Murray v. The Netherlands (para. 101).

21 See Harakchiev and Tolumov (para. 264).
} 
enable such prisoners to make progress towards their rehabilitation."22 Such an obligation exists in situations where it is the prison regime or the conditions of detention that obstruct rehabilitation. ${ }^{23}$ This requires positive state action to promote rehabilitation, which means a state effort to prevent and neutralize the unwanted harmful side effects of incarceration. This implies that the rehabilitative activities should limit the detrimental effects of the detention itself. ${ }^{24}$ Both the regime and the conditions of a prisoner's incarceration may be relevant to the question of whether a (life) prisoner is given the opportunity for rehabilitation..$^{25}$ One of the aspects of the prison regime and the conditions of detention that can seriously hinder a prisoner in his or her process towards rehabilitation is limiting contact with the outside world. For instance, in the case of Khoroshenko v. Russia, contact with the outside world was limited because telephone calls were limited to emergency calls and visits from relatives were limited to once every six months, for no longer than four hours, with a maximum of two adult visitors. During the visits, direct physical contact was not possible: Khoroshenko was separated from his visitors by a glass partition and a prison guard was present and within listening distance at all times. Providing prisoners with a real opportunity for rehabilitation also requires that prisoners are allowed to engage in social contact, work or education. ${ }^{26}$ The duration of (and the strictness of) the prison regime and the possibilities for alteration are also significant. In Khoroshenko v. Russia, the restrictions mentioned above were all combined within one regime for a fixed duration of time and could not be altered. ${ }^{27}$

Although the ECHR has previously ruled that states cannot (in general) be obliged to provide prisoners with rehabilitation or reintegration programmes and activities, such as courses or counselling, a 'real opportunity to rehabilitation' may imply that (life) prisoners, depending on their individual situation, are allowed to undergo (medical, psychological of psychiatric) treatment or therapies that are appropriate to them, with a view to facilitating their rehabilitation. The case of Murrayv. The Netherlands makes it clear that life prisoners who have been diagnosed with a mental disability and/or mental condition

\footnotetext{
22 See Murrayv. The Netherlands, 26 April 2016, para. 104.

23 See Harakchiev and Tolumov (para. 266).

24 D. van Zyl Smit and S. Snacken, op. cit., pp. 83-84.

25 Khoroshenko v. Russia (para. 122), Harakchiev and Tolumov (para. 265).

26 In the Harakchiev case these possibilities were seriously limited because he remained in permanently locked cells and isolated from the rest of the prison community throughout the entire period of his incarceration. See Harakchiev and Tolumov (paras. 265-266).

$27 \quad$ Khoroshenko v. Russia (para. 130).
} 
should only be detained under the above conditions. They must be given appropriate treatment and a 'realistic opportunity' to rehabilitate themselves, so that they might hope to be released some day. The lack of such an opportunity may result in the de facto reducibility of the life sentence. According to the ECHR, this implies that prisoners "should also be allowed to take part in occupational or other activities where these may be considered to benefit rehabilitation". ${ }^{28}$ This does not, however, clarify the implications of the positive obligation of states because in choosing the facilities, measures or treatments that are required in order to enable a (life) prisoner to rehabilitate himself or herself, states have a wide margin of appreciation. The obligation under Article 3 is to be interpreted in a way that does not impose an excessive burden on national authorities. ${ }^{29}$

With regard to cases of persons who have already served the punishment element of their sentence and are in detention solely because of the risk they pose to the public, the Court emphasizes the need to encourage the rehabilitation of such offenders. In the case of James, Wells and Lee, a real 'opportunity for rehabilitation' meant that the prisoners were required to be provided with reasonable opportunities to engage in courses or education aimed at helping them to address their offending behaviour and the risks that they posed. However, Article 5(1) does not impose any absolute requirement for prisoners to have immediate access to all the courses that they may require and that any restrictions or delays encountered as a result of resource considerations must be reasonable in all the circumstances of the case. ${ }^{30}$

It follows from the above that states should make a case-by-case assessment in order to determine what a 'proper opportunity to rehabilitation' implies for the individual prisoner involved. When considering rehabilitation, the individual needs of the prisoners should be leading in determining the rehabilitative activities provided. Individual needs will vary from case to case. For instance, providing a life prisoner with 'meaningful daily activities and activities focused on improving social functioning, ${ }^{31}$ will not be sufficient if the life prisoner in question suffers from serious mental health problems which cause the prisoner to continue to pose a risk to society and who is therefore not eligible for release.

\footnotetext{
$28 \quad$ Murray v. The Netherlands (para. 109).

29 Murray v. The Netherlands (para. 110).

30 See James, Wells and Lee, 18 September 2012, para. 218.

31 As proposed in the new Dutch policy with regard to the enforcement of the life sentence, which will be described in para. 3.2.
} 


\subsection{Rehabilitation in Europe}

Although the recent judgments of the European Court of Human Rights with regard to the rehabilitation of prisoners have been progressive and this will undoubtedly affect the national interpretation of this concept, this does not mean that there is a European consensus on the concept. First of all, the way in which the principle is enshrined in law varies from country to country. A constitutional right to rehabilitation is recognized in several European countries. For instance, in Spain, the constitution provides that prison sentences shall be oriented towards the re-education and social rehabilitation of offenders. ${ }^{32}$ The Italian constitution specifies that punishment shall aim to reform the person upon whom sentence is passed. ${ }^{33}$ In other countries, the aim of rehabilitation is laid down in law. ${ }^{34}$ Secondly, the interpretation of the concept of rehabilitation by on the one hand the ECHR and on the other hand the member states may vary, as well as interpretation of this principle by different states. An analysis of the criminal justice system of Germany and The Netherlands with regard to the rehabilitation principle will further clarify the different explanations of this concept that are given at the national level.

\subsection{Germany}

Resozialisierung or social reintegration is the most important aim of punishment in Germany. The Resozialisierungsgrundsatz serves as the overarching principle for sentencing, for the way in which sentences are applied and for dealing with offenders once the sentence has been served. ${ }^{35}$ Accordingly, the German Prison Act defines 'resozialisierung' as the primary purpose of prison sentences, against which all restrictions imposed on prisoners are to be evaluated. According to German scholars and other experts, the concept of

32 Constitucíon Article 25(2): 'Las penas privativas de libertad y las medidas de seguridad estarán orientadas hacia la reeducación y reinserción social y no podrán consistir en trabajos forzados.', which translates as: 'Custodial sentences and security measures will be aimed at reeducation and social rehabilitation and may not involve forced labour.'

33 Costituzione Article 27: 'Le pene non possono consistere in trattamenti contrari al senso di umanità e devono tendere alla rieducazione del condannato' which translates as: 'Punishment cannot consist in treatment contrary to human dignity and must aim at rehabilitating the condemned.' See for references to case law of the Italian Constitutional Court Vinter and others v. the United Kingdom (para. 72).

34 In The Netherlands, for instance, this principle is laid down in the Penitentiary Principles Act.

35 Morgenstern (2015). 
resocialization remains vague, however. The meaning of this concept depends on who applies it and for what purpose. ${ }^{36}$

In spite of this lack of clarity, the concept of resocialization has not been seriously challenged in Germany since the 1970s. This is due to a decision by the German Federal Constitutional Court (Bundesverfassungsgericht) in 1973, in which the Court recognized the right to resocialization as an integral part of the rights guaranteed by the constitution. ${ }^{37}$ It follows from this decision that social reintegration rests on two constitutional pillars. ${ }^{38}$ Firstly, the principle of resocialization is derived from respect for human dignity: individuals have a right to dignity and a right to develop their personality freely (Articles 1 and 2 Basic Law). Secondly, it is founded on the notion that social reintegration is the end towards which the penal system should strive, in accordance with the constitutional principle of the 'social state' (Sozialstaatsprinzip, Article 20 (3) Basic law). This notion of the 'social state' implies that the state has a constitutional obligation to assist "those groups in the community who, because of personal weakness or shortcomings, incapacity or social disadvantage, have been adversely affected in their social development; prisoners and ex-prisoners belong to this group. Not least, resocialization serves to protect society itselfafter all, it is in the interests of society that offenders do not re-offend...." ${ }^{39}$ From a constitutional point of view, the principle of resocialization implies both negative fundamental rights that protect against state infringement and positive rights that oblige the state to act. The concept of resocialization has, then, acquired a central position in criminal science and criminal politics. Recently, the concept of 'Resozialisierung' has become increasingly popular. ${ }^{40} \mathrm{Al}$ though the concept of resocialization and its legitimacy have been the subject of debate over the years, the aim of resocialization itself enjoys broad support. ${ }^{41}$ In later jurisprudence, the Federal Constitutional Court has provided further detail about how resocialization is to be understood and implemented as a positive right to state action and assistance, particularly with regard to the enforcement of prison sentences (including life sentences) and prison conditions, remuneration for prison work, prison leave, and so forth.

36 H. Cornel, 'Zum Begriff der Resozialisierung', in H. Cornel, G. Kawamura-Reindl, B. Maelicke and B.-R. Sonnen (eds) Resozialisierung (Baden Baden: Nomos, 2009), p. 27.

37 See judgement of 5 June 1973, BVerfGE 35, 202 (Lebach decision).

38 Morgenstern (2015); also C. Morgenstern, 'Judicial rehabilitation in Germany - the use of criminal records and the removal of recorded convictions', 3 European Journal of Probation (2011) 20-35.

39 BVerfGE 35, 202, 235-236 Lebach decision.

40 Cornel (2009), pp. 27, 34.

41 Cornel (2009), p. 34. 


\subsection{The Netherlands}

Resocialisatie or resocialization is one of the aims of the execution of sentences in The Netherlands. The meaning of the concept of resocialization under Dutch law is limited to the duration of the sentence rather than dealing with the offender after the sentence has been served. ${ }^{42}$ For custodial sentences, the resocialization principle has been enshrined in Dutch law since $1951{ }^{43}$ Shortly after World War II, the legal position of prisoners was significantly improved through the introduction of inter alia the Penitentiary Principles Act. Unlike in Germany the concept of resocialization has been the object of debate in The Netherlands in recent years. As a result, the form and content of this principle has changed significantly. This is best reflected in a recent change to the Article that defines the principle. ${ }^{44}$ Since its introduction in 1951, this Article had read as follows: "While maintaining the character of the custodial sentence, the enforcement of such sentence must be subservient to every extent possible to the preparation of the person involved, for his return to society." With effect from 1 July 2015, this Article was amended and made stricter, because resocialization was made dependent on the "behaviour of the prisoner". Furthermore, the Article explicitly states that "the protection of society and the interests of the victims or their surviving relatives should be taken into account" when deciding on the resocialization of the prisoner. ${ }^{45}$

The Dutch concept of resocialization thus contrasts sharply with the German concept. Although Dutch law formulates resocialization as a punishment, the concept in The Netherlands is applied much more narrowly because it is applied solely to prisoners who are motivated to reform.

There are several reasons for this narrower Dutch interpretation of the concept of resocialization. First of all, the development of this principle should be viewed in the context of the initial optimism and faith in the ideal of rehabilitation that followed World War II, which was quickly replaced by the pessimism of the 1970 with the rise of the 'Nothing Works' movement. In The Netherlands, this resulted in a prison policy with less emphasis on rehabilitation and more emphasis on the principle of minimum restrictions.

Secondly, the changing interpretation of the concept of rehabilitation is the result of the Dutch policy on prison that has been in place since 1994. This obliges the state to link rehabilitation to the conduct and responsibility of

42 Parliamentary Papers II 2004/05, 27834, 36.

43 The rehabilitation principle as such also applies to other sentences. New legislation that applies this principle to other sentences, such as community sanctions, is currently being prepared (Article 6.1.3 Criminal Procedural Code). 
individual prisoners. Rehabilitation is targeted at prisoners who are motivated to participate in rehabilitative activities. ${ }^{46}$ One of the primary features of this policy is that prisoners are held responsible for their behaviour while in detention. ${ }^{47}$ This policy has been criticized by legal scholars ${ }^{48}$ because it is doubtful whether every detainee is able to cope with this responsibility. After all, the majority of prisoners have less developed social skills than the norm and need basic support in the areas of social learning, education and job training. One aspect that they need to learn is how to take responsibility for their own actions. By limiting rehabilitation to those prisoners who are already motivated and therefore presumably already have a greater sense of responsibility, a large majority of inmates are excluded from rehabilitative activities-probably those who need it most. This interpretation of the rehabilitation principle is at odds with the European legal frameworks outlined above, including a rehabilitation principle that applies to all detainees.

Thirdly, the current definition of rehabilitation reflects a development which is evident across Europe: an increasing emphasis on victim rights. ${ }^{49}$ When deciding on the resocialization of a prisoner, judges and prison authorities are required to take the protection of society and the interests of the victims or their surviving relatives into account. Of course, this does not mean that victims' rights were not taken into account before the amendment of the Article. Nor does it mean that judges place more emphasis on the rights of the victims than previously or that priority is given to victims' rights over the rights of the offender. For example, in the case of the convicted murderer of a wellknown politician, which had a significant impact on Dutch society, the Council for the Administration of Criminal Justice and the Protection of Juveniles (de Raad voor de Strafrechtstoepassing en Jeugdbescherming, RSJ), the highest penitentiary court in The Netherlands, ruled that "as time passes and the actual release of Van der G. approaches, good preparation for that release will prevail over the possibility of social unrest and any risks that leave may entail", thereby prioritizing the interests of the convicted in obtaining leave over the interest of the (surviving relatives of the) victim and of wider society. ${ }^{50}$

\footnotetext{
46 Policy 'Active Detention' of 1994 (beleidsnota Werkzame detentie, 1994).

47 Program 'Detention and Customised Treatment' of 2006 (programma Detentie en Behandeling op Maat, 2006).

48 M. Boone and W. van Hattum, “Promoveren en degraderen' van gedetineerden', Nederlands Juristenblad (2014) 2179-2184.

49 See, for instance, Directive 2012/29/EU of the European parliament and of the Council of 25 October 2012 establishing minimum standards on the rights, support and protection of victims of crime, and replacing Council Framework Decision 2001/220/JHA.

RSJ 10 December 2013, no. 13/3433/GV.
} 
In political terms, the discussion on rehabilitation is a sensitive area, mainly because the discussion is conducted in the context of life imprisonment. The rehabilitation principle is interpreted in a strict sense with regard to life prisoners in The Netherlands and it should be understood that there is a great deal of political resistance and unwillingness to make any changes with regard to life imprisonment. For instance, for some considerable time, the Minister of Security and Justice and his State Secretary took the view that the principle of resocialization had to be interpreted in such a way that it would not apply to life prisoners and that it would only acquire meaning if a decision were made to release a life prisoner. ${ }^{51}$ As such, although the rehabilitation principle is in practice applied by drawing up a detention and reintegration plan for detainees as soon as the period of detention starts, life prisoners are excluded from this, because they would not be eligible for release unless and until a specific decision was made that this should happen.

The rehabilitation of life prisoners has been the subject of some debate and has in some cases given rise to legal action against the Dutch state by Dutch life prisoners. ${ }^{52}$ In several cases, judges have ruled that the state was obliged to offer the opportunity for rehabilitation to the life prisoner involved. In one case dating from 18 September 2014 (case C), the ruling judge noted that no activities of any kind aimed at the rehabilitation of the life prisoner had been undertaken and ordered the state to begin such rehabilitative activities so that the life prisoner's progress towards rehabilitation could be assessed at the next request for pardon. ${ }^{53}$ In another case (case Y), the judge ordered the state to grant the life prisoner unescorted leave. ${ }^{54}$

The fact that Dutch policy with regard to life imprisonment does not comply with Article 3 of the Convention was recently confirmed by the case of Murray $v$. The Netherlands. Murray was serving a life prison sentence on the island of Aruba. ${ }^{55} \mathrm{He}$ had already been imprisoned for about thirty years when he submitted his application with the ECHR in 2010. The Grand Chamber ruled unanimously that there had been a violation of Article 3 of the Convention, because the life sentence was not de facto reducible, as required by this Article.

51 Appendix to Parliamentary Proceedings II 2011/12, 832, answer to question 6; Appendix to Parliamentary Proceedings II 2013/14, 1336, answer to question 7.

See W.F. van Hattum and S. Meijer, 'An administrative procedure for life prisoners: law and practice of royal pardon in The Netherlands' in D. Van Zyl Smit and C. Appleton (eds), Life imprisonment and Human Rights (Cumnor: Hart/Bloomsbury, 2016) pp. 141-165. District Court of The Hague, 18 September 2014, ECLI:NL:RBDHA:2014:11541.

54 District Court of The Hague, 10 July 2014, ECLI:NL:RBDHA:20148409.

55 Which is a part of the Kingdom of The Netherlands. 
The lack of any kind of medical or psychiatric treatment or even of any assessment of treatment needs meant that any request by Murray for a pardon could not in practice lead to the conclusion that he had made such significant progress towards rehabilitation that his continued detention would no longer serve any penological purpose. ${ }^{56}$ Various requests for pardon were inter alia based on the assessment that the risk of recidivism which he was considered to pose continued to exist. This became the sole reason for the refusal to grant him release of any kind in the later years of his incarceration.

Immediately after this, the Dutch Secretary of State, with reference to the Murray case, announced a change in policy with regard to the enforcement of life sentences. ${ }^{57}$ Nevertheless, the Secretary of State continues to emphasize the 'life means life' policy with regard to life sentencing. If a judge decides to impose a life sentence, the convicted person should not generally expect to return to society under this policy. The changes made involved the introduction of periodical reviews and the establishment of an advisory board. The first periodic review takes place after the life prisoner has been detained for 25 years. The Secretary of State explained his choice of a 25-year period with reference to the distinction between temporary prison sentences with a maximum fixed-term of 30 years and life sentences in Dutch criminal law. Persons who have been sentenced to a maximum prison sentence of 30 years are eligible for release after a period of 20 years. According to the Secretary of State, the actual imprisonment of a person sentenced to life imprisonment should be substantially longer than the maximum temporary sentence. Furthermore, the Secretary of State pointed out that the ECHR has indicated that in comparative and international law there is clear support for the institution of a dedicated mechanism that guarantees a review no later than 25 years after the imposition of a life sentence, with further periodic reviews thereafter. ${ }^{58}$ During the first 25 years of the life sentence, the emphasis is on the retributive aim of imprisonment. According to the Secretary of State, this implies that during that time, no rehabilitative activities, relating to employment and income, shelter, ID, debt and care, are to be provided. By contrast, activities relating to humane detention, such as meaningful daily activities and activities that focus on improving social functioning, are provided. Furthermore, life prisoners are provided with regular medical care. After 25 years, a review procedure is initiated: a specially appointed advisory board assesses whether the life prisoner is

\footnotetext{
56 See Murrayv. The Netherlands (paras. 125-127).

57 Parliamentary Papers II, 2015/16, 29279, 325. See also the reaction of the State Secretary on life imprisonment of 2 September 2016 in which he reaffirms his position.

$5^{8} \quad$ Vinter and others $v$. the United Kingdom (para. 120).
} 
eligible for rehabilitation and, if so, for which rehabilitative activities. The advisory board also assesses how soon any subsequent review should take place. In the context of this review procedure, the aim of retribution is balanced with other aims and circumstances, such as the protection of society, the danger of recidivism, the interests of victims and/or their surviving relatives, and the age and medical condition of the life prisoner concerned. The advisory board is explicitly not required to form an opinion on the termination of the life sentence. The review procedure also implies that the life prisoner is transferred temporarily to a special facility (the Pieter Baan Centrum) which specializes in psychological and psychiatric assessments of prisoners, and carries out observations. Here, an assessment is made of the development of the personality of the prisoner in question as well as an assessment of the potential for violent behaviour. Based on the advice of the advisory board, the Secretary of State then decides on whether rehabilitative activities will be provided. If the Secretary of State decides that such activities should indeed be provided, a detention and reintegration plan is drawn up.

It is clear from the European legal framework outlined above that these changes to the policy of The Netherlands are not consistent with the requirements set by the case law of the ECHR. The most troubling aspect of this new policy is that the rehabilitation principle is not seen as applicable to life prisoners until a period of 25 years has passed. This is due to the fact that for the first 25 years, the emphasis is solely on the retributive aim of imprisonment and that during that period, no rehabilitative activities are to be offered. It is clear that this goes against the case law of the ECHR, which requires that a review procedure should take place after 25 years of imprisonment with "a view to its commutation, remission, termination or the conditional release of the prisoner"59 and not only with a view to providing rehabilitative activities. This review procedure should evaluate "whether any changes in the life prisoner are so significant, and such progress towards rehabilitation has been made in the course of the sentence, as to mean that continued detention can no longer be justified on legitimate penological grounds." ${ }^{60}$ To be eligible for release, the process of rehabilitating the prisoners should begin well before 25 years have elapsed. Furthermore, a life prisoner is entitled to know "at the outset of his sentence, what he must do to be considered for release and under what conditions". 61

It is therefore not surprising that almost immediately after the publication of the revised policy, a life prisoner who had already been detained for 23 years

59 Vinter and others $v$. the United Kingdom (para. 109).
$60 \quad$ Vinter and others $v$. the United Kingdom (para. 119).
$61 \quad$ Vinter and others $v$. the United Kingdom (para. 122). 
and six months argued before the Court that he should be given rehabilitative activities immediately. The Court ruled in his favour, expressing the view that rehabilitative activities are indispensable to any assessment of whether the life prisoner should be eligible for release after 25 years and ordered the state to develop a reintegration plan within 10 days of the court ruling. ${ }^{62}$

Shortly after the Murray case, the Dutch Supreme Court also ruled that the Dutch system of life imprisonment constitutes a violation of Article 3 of the Convention because the current policy implies that life sentences are not $d e$ facto reducible as required by Article 3. The Supreme Court also decided that a review procedure should be put in place and stipulated the conditions under which that review should take place. ${ }^{63}$ The Dutch Supreme Court-citing the ECHR in the Vinter case-stipulated that as part of the review procedure, an assessment should be made as to whether any changes in the life prisoner are significant enough, and whether sufficient progress towards rehabilitation has been made in the course of the sentence, to mean that continued detention may no longer be justified on legitimate penological grounds. ${ }^{64}$ The progress of the life prisoner and their opportunities for rehabilitation should be considered as part of the assessment. A life prisoner is entitled to know at the outset of his sentence what he or she needs to do to be considered for release and under what conditions, including when a review of the sentence will take place or may be sought. In a truly unique decision, the Supreme Court adjourned the case until 5 September 2017 to allow the Secretary of State the opportunity to revise the existing policy on life sentences. It is likely that the Secretary of State will revise his earlier plans, but this will undoubtedly run into political resistance. ${ }^{65}$

Rehabilitation as a Positive Obligation

\subsection{On What Grounds Can Rehabilitation be Considered a Positive Obligation of the State?}

Although the ECHR has already pointed out in previous cases that the emphasis in European penal policy now is on rehabilitation, since the Murrayv. The Netherlands case there can be no ambiguity regarding whether rehabilitation

\footnotetext{
62 District Court of The Hague, 10 August 2016, ECLI:NL:RBDHA:2016:9397.

63 Dutch Supreme Court, 5July 2016, ECLI:NL:HR:2016:1325, para. 3.3.

64 See Vinter and others $v$. the United Kingdom (para. 119).

65 The first Parliamentary debate following the plans of the State Secretary on life imprisonment has already taken place on 8 September 2016.
} 
is a positive obligation. But on what grounds can rehabilitation be regarded as a positive obligation? Both Rotman and Ploch have explored various justifications for rehabilitation. ${ }^{66}$ These justifications reflect opinions about the underlying reasons why prisoners should be rehabilitated.

Rotman distinguishes between two models of rehabilitation, an authoritarian and paternalistic model and a humanistic, liberty-centered model. In the first model of rehabilitation correctional policies and government interests prevail over the individual development of the prisoner. Rehabilitation is used to change the personality of the offender. ${ }^{67}$ According to Ploch, in this model rehabilitation can be seen as a mean to redress certain macro-level socioeconomic inequalities and problems. For example, rehabilitation can be used to provide certain skills to prisoners to increase their chance of job stability upon release, which in turn can reduce recidivism. The problem with this theory is that rehabilitation might focus too much on measurements of progress and benefits to larger society. The authoritarian and paternalistic model also gives room for a cost-benefit analysis to determine whether the social benefits of rehabilitation (increasing job stability, improving education of prisoners and reducing recidivism) outweigh the costs of providing rehabilitation services. ${ }^{68}$

The humanistic, liberty-centred model on the other hand assumes that change can only result from the individual's own insight and uses dialogue to encourage the process of self-discovery. It encourages prisoners self-awareness as a means to transformation. Prisons should provide rehabilitation out of respect for the prisoners capacity to act morally and rationally and to assist prisoners in exercising their own autonomy. Other than the authoritarian and paternalistic model this model is individualized and rehabilitation is viewed from the perspective of the offender. Prisoners should receive rehabilitation based on their inherent worth as human beings. In this model prisoners are also regarded as possessors of rights, including a right to rehabilitation.

Both theories can be recognised in the case law of the ECHR. The ECHR already stated in 2007 in the Dickson case that 'While rehabilitation was recognised as a means of preventing recidivism, more recently and more positively it constitutes rather the idea of re-socialisation through the fostering of personal responsibility. ${ }^{\prime 9}$ However, the humanistic-liberty centred model has

66 Rotman (1986), 1025; also A. Ploch, 'Why dignity matters: dignity and the right (or not) to rehabilitation from international and national perspectives', 44 International Law and Politics (2012) 887-949.

$67 \quad$ Rotman (1986), at 1025 .

68 Ploch (2012), at 898.

69 See Dickson v. the United Kingdom, 4 December 2007, para. 28. 
gained importance over the last decade. The existence of a positive obligation to rehabilitation seems to be based primarily on respect for human dignity. The concept of human dignity became prominent in international dialogue in the Twentieth Century, especially after World War II and lies, as the ECHR has often stated, at the very heart of the Convention system. ${ }^{70}$ It would be incompatible with human dignity to forcefully deprive a person of his or her freedom without efforts towards that person's rehabilitation (and the prospect of one day regaining his or her liberty). ${ }^{71}$

Recognising rehabilitation as a positive obligation-grounded in human dignity - is important, because it makes clear that rehabilitation is at all times to be taken into account and cannot be set aside by other concerns such as the effectiveness of rehabilitative efforts and prison authorities concerns such as cuts or staff shortage. These other concerns can easily result in a policy that in some circumstances-for instance, depending on the economic situation or ruling political party at some point in time-encourages rehabilitation, while discouraging it at other times.

\subsection{What are the Consequences of Recognizing Rehabilitation as a Positive Right?}

The importance of the ECHR's recognition of rehabilitation as a positive right should not be underestimated. The legal comparison between Germany and The Netherlands shows that the principle of rehabilitation is being interpreted in various ways, depending on the nation state in question. The importance of recognizing rehabilitation as a positive obligation is that it makes the provision of rehabilitative activities legally enforceable, which allows courts to intervene in the case of administrative reluctance. ${ }^{72}$ The question of what rehabilitation implies in the context of a particular case may be submitted to the judge. Dutch practice in the area of life imprisonment shows the importance of the role of the judiciary in enforcing life imprisonment, and how the courts can provide a counterbalance to the power of the administration.

The advantage of declaring rehabilitation to be a positive obligation (and the clear scope of the rehabilitation principle) is that it binds states to abide by certain standards and should ensure a minimum level of protection. It follows from the case law of the ECHR that the rehabilitation principle remains necessarily vague and that states should make a case-by-case assessment in

\footnotetext{
$70 \quad$ Vinter and others $v$. the United Kingdom (para. 113), Pretty v. the United Kingdom (para. 65) and V.C. v. Slovakia (para. 105).

71 See Murrayv. The Netherlands (paras. 101-104).

72 See also Rotman, op. cit., at 1027.
} 
order to determine what a "proper opportunity to rehabilitation" implies for the prisoner involved. This is not necessarily negative. In this regard, a warning is in place: the obligation to pursue the policy aim of rehabilitation cannot be reduced to the sum of different rights that states can be expected to and are obliged to provide because this would involve the risk that states may limit themselves to providing these rights but lose sight of the overall obligation to pursue a policy aimed at rehabilitation. In this way, states would be immune to criticism 'as long as they gave prisoners their rights' - however few rights this may include at any given moment in time. ${ }^{73}$

\section{Conclusion}

Although the emphasis in European penal policy now is on the rehabilitative purpose of imprisonment, the concept of rehabilitation remains ambiguous. As our legal comparison between Germany and The Netherlands has shown, there is no agreement between these states on the nature of this principle and how it should be interpreted. More research on how this principle in other European countries is interpreted is much needed. The legal comparison between Germany and The Netherlands does however emphasizes the importance of clarifying the scope of the principle of rehabilitation at the European level. The recognition of the rehabilitation principle as a positive obligation on the part of the state is a very important step in this regard. The ECHR has made it clear that States are obliged to offer (life) prisoners a proper opportunity for rehabilitation. This positive obligation can be construed on the basis of respect for human dignity, which lies at the heart of the European Convention system. What a "proper opportunity" for rehabilitation implies, depends on the specific circumstances of the case. When considering the question of rehabilitation, the individual needs of the prisoners should be leading when determining rehabilitative activities. The recent developments in The Netherlands can be used as an example for other European countries. These developments show what rehabilitation as a positive obligation implies and also that the importance of the recognition of the rehabilitation principle as a positive obligation is that it enables (life) prisoners to present their case to a judge, and that it makes rehabilitation legally enforceable. At the same time, it is important to observe that rehabilitation is not the sum of various other rights, such as the right to furlough or treatment, but should lie at the basis of the penal policy of nation states. 